\title{
Edaphic macrofauna in degradation of animal and vegetable residues
}

\author{
R. N. Schubert ${ }^{*}$, T. B. G. A. Morselli, S. M. Tonietto ${ }^{c}$, J. M. O. Henriquez ${ }^{a}$, R. D. Trecha ${ }^{a}$, \\ R. P. Eid ${ }^{a}$, D. P. Rodriguez ${ }^{a}$, S. R. Piesanti ${ }^{a}$, M. R. S. Maciel ${ }^{a}$ and A. P. F. Lima ${ }^{c}$ \\ aPrograma de Pós-graduação em Sistemas de Produção Agrícola Familiar - PPGSPAF, Departamento de Fitotecnia, \\ Faculdade de Agronomia Eliseu Maciel - FAEM, Universidade Federal de Pelotas - UFPel, \\ Campus Universitário, s/n, CEP 96160-000, Capão do Leão, RS, Brasil \\ bDepartamento de Solos, Faculdade de Agronomia Eliseu Maciel - FAEM, Universidade Federal de Pelotas - UFPel, \\ Campus Universitário, s/n, CEP 96160-000, Capão do Leão, RS, Brasil \\ 'Laboratório de Biologia de Solos - LBS, Departamento de Solos, Faculdade de Agronomia Eliseu Maciel - FAEM, \\ Universidade Federal de Pelotas - UFPel, Campus Universitário, s/n, CEP 96160-000, Capão do Leão, RS, Brasil \\ *e-mail: ryannslp@yahoo.com.br
}

Received: August 30, 2017 - Accepted: January 29, 2018 - Distributed: August 31, 2019

\begin{abstract}
The objective of this study was to evaluate the ability to degrade organic matter by edaphic macrofauna (worms), carbon/nitrogen $(\mathrm{C} / \mathrm{N})$ ratio and hydrogenation potential $(\mathrm{pH})$ during the vermicomposting process in different organic residues. The treatments were constituted by organic residues of animal origin (bovine, ovine and equine manure) and vegetable (herb-checkmate and coffee drag), which were conditioned in plastic pots with a capacity of 10 liters, comprising five treatments in a completely randomized experimental design, with five replications. Were inoculated 150 earthworms of the species Eisenia foetida, into each plot. After 87 days, the evaluation of the multiplication of the earthworms was carried out, through its manual count and its cocoons. At the beginning and at the end of the experiment, the samples were submitted to analysis of humidity at $60^{\circ} \mathrm{C}, \mathrm{pH}$, volumetric density, chemical analysis of macronutrients and $\mathrm{C} / \mathrm{N}$ ratio. There was a dominance of worms and cocoons in the process of vermicomposting in the residues of ovine manure and herb-checkmate. The macronutrients $(\mathrm{P}, \mathrm{K}$ and $\mathrm{Mg}$ ) and $\mathrm{C} / \mathrm{N}$ ratio were higher in the vegetal residues, while for $\mathrm{N}$ higher values were found in ovine manure and coffee drag treatments, and for $\mathrm{Ca}$ higher value among treatments was observed in the coffee drag treatment at the end and the lowest value at initiation. The results obtained in this study demonstrate the importance of the edaphic macrofauna to the vermicomposting process, since it allows more information about its influence on the continuity of soil organic matter decomposition processes.
\end{abstract}

Keywords: macrofauna edaphic, Eisenia foetida, organic waste.

\section{Macrofauna edáfica no processo de vermicompostagem de resíduos animais e vegetais}

\section{Resumo}

Este estudo objetivou avaliar a capacidade de degradar a matéria orgânica pela macrofauna edáfica (minhocas), a relação carbono/nitrogênio $(\mathrm{C} / \mathrm{N})$ e o potencial hidrogeniônico $(\mathrm{pH})$, durante o processo da vermicompostagem em diferentes resíduos orgânicos. Os tratamentos foram constituídos por resíduos orgânicos de origem animal (esterco bovino, ovino e equino) e vegetal (resíduo de erva-mate e borra-de-café), os quais foram acondicionados em vasos plásticos com capacidade de 10 litros, compondo cinco tratamentos em delineamento experimental inteiramente casualisado, com cinco repetições. Foram inoculadas 150 minhocas da espécie Eisenia foetida, em cada recipiente. Após 87 dias, foi realizada a avaliação da multiplicação das minhocas, através da sua contagem manual e seus casulos. Os resíduos foram submetidos, ao inicio e ao final do experimento, a análises de umidade a $60{ }^{\circ} \mathrm{C}, \mathrm{pH}$, densidade volumétrica, análise química de macronutrientes e relação $\mathrm{C} / \mathrm{N}$. Houve uma dominância de minhocas e casulos no processo da vermicompostagem nos resíduos de esterco ovino e erva-mate. Observou-se para os macronutrientes $(\mathrm{P}, \mathrm{K} \mathrm{e} \mathrm{Mg})$ e para a relação $\mathrm{C} / \mathrm{N}$ uma maior quantidade nos resíduos vegetais, enquanto que para $\mathrm{N}$ valores maiores foram encontrados nos tratamentos esterco ovino e borra-de-café, e para $\mathrm{Ca}$ o maior valor entre os tratamentos foi observado no tratamento com borra de café ao final e o menor valor no inicio. Os resultados obtidos neste estudo demonstram a importância da macrofauna edáfica para o processo da vermicompostagem por possibilitar maiores informações sobre sua influência na continuidade dos processos de decomposição da matéria orgânica.

Palavras-chave: macrofauna edáfica, Eisenia foetida, resíduos orgânicos. 


\section{Introduction}

The edaphic macrofauna comprises the largest invertebrates (organisms larger than $10 \mathrm{~mm}$ in length or more than $2 \mathrm{~mm}$ in diameter) such as earthworms, larval and adult beetles, centipedes, termites, ants, snake lice (milipéias), tatuans e arachnids (Wolters, 2000; Lavelle and Spain, 2001).

Some of these, such as earthworms, are called "ecosystem engineers" because their activities lead to the creation of biogenic structures, modifying the physical properties of the soil on which they live and the availability of resources to other organisms (Wolters, 2000). As a result of the interaction between the chemical, physical and biological processes, they have been shown to be a good indicator of soil quality (Doran and Zeiss, 2000; Silva et al., 2006; Silva and Amaral, 2013).

Of the numerous earthworm species known in the world (Sharma et al., 2005), Eisenia foetida is the most used in captivity (vermicomposting) due to its wide distribution, tolerance to temperature fluctuation, resistance to handling, ability to live in organic residues with different degrees of humidity, in addition to its high reproductive capacity and rapid growth (Aquino and Nogueira, 2001; Pereira et al., 2005).

Although the microorganisms are responsible for the biochemical degradation of organic matter, earthworms influence physically and biochemically in the process (Naddafi et al., 2004), because they transform it into a compound of better quality than those produced by the traditional method of composting, making the vermicompost a low-cost, simple and efficient process (Atiyeh et al., 2001).

In this sense, the objective of this work was to evaluate the ability to degrade organic matter by edaphic macrofauna (earthworms), carbon/nitrogen $(\mathrm{C} / \mathrm{N})$ ratio and hydrogen ionic potential $(\mathrm{pH})$ during the vermicompost process in different residues organic.

\section{Material and Methods}

The work was executed between May and July 2016, In the Laboratório de Biologia do Solo (LBS) of the Departamento de Solos (DS) of the Faculdade de Agronomia Eliseu Maciel (FAEM), Campus Capão do Leão, Universidade Federal de Pelotas (UFPel), Rio Grande do Sul (RS), Brazil, whose geographic coordinates are: South latitude $31^{\circ} 52^{\prime}$ South, longitude $52^{\circ} 21^{\prime}$ and an altitude of 13 meters above sea level (Mota et al., 1993).

After an initial stabilization process, with weekly recycling of the waste, in order to aerate the medium and make it acceptable for earthworms of the species Eisenia foetida, the research was conducted using a completely randomized experimental design (DIC) composed of five different organic residues: bovine manure (EB); equine manure (EE); sheep manure (EO); residue herb-checkmate (EM) e residue of coffee drag (BC). In the laboratory, each treatment with different residues, which were distributed randomly in a horizontal table, totaling 25 experimental units, conditioned in plastic plots with a capacity of 10 liters.
On the first day of the experiment, 150 worms were inoculated in each plot, duly covered with a cloth of tissue fastened with an elastic to prevent the exit of these earthworms or the entrance of other unwanted organisms. After 87 days, the evaluation of the multiplication of the earthworms was carried out, through the manual count of worms and cocoons, similar to that done by Bassaco et al. (2015) at 90 days post inoculation.

For the determination of the multiplication index of earthworms, was used the formula IM $=\mathrm{Pf} / \mathrm{Pi}$, where $\mathrm{Pf}=$ final population of worms and $\mathrm{Pi}=$ initial population of worms, corresponding to the number of inoculated matrices (Antoniolli et al., 2009).

The residues were submitted, at the beginning and at the end of the experiment, the analysis of humidity, as recommended by Normative Ruling $n^{\circ}$. 17, dated May 21, 2007, of the Brazilian Ministry of Agriculture, Livestock and Supply (Brasil, 2007), weighing $20 \mathrm{~g}$ of each material and placed in an kiln with an average temperature of $60-65{ }^{\circ} \mathrm{C}$ for a period of 48 hours until reaching constant weight. At the end of this period, these materials were again weighed to obtain the dry matter.

For the determination of the $\mathrm{pH}$ of the different substrates, as readings were made in suspensions of substrate: deionized water in a ratio of $1: 3(\mathrm{v}: \mathrm{v})$, through the potentiometer, where $10 \mathrm{~g}$ of each material was added with $30 \mathrm{~mL}$ of deionized water. As samples were homogenized individually for 5 minutes, and after 30 minutes, perform a $\mathrm{pH}$ reading with the aid of a previously calibrated digital potentiometer. This procedure is repeated at the beginning of the experiment and at the end of the experiment. In the same way as the self-compacting method (Fermino, 2014), based on the VDLUFA method, adopted in Germany (Röber and Schaller, 1985) and Austria (Baumgarten, 2002). It is the official method adopted by MAPA (Brasil, 2004), and calculated according to the formula: $\mathrm{D}=\mathrm{M} / \mathrm{V}\left(\mathrm{g} . \mathrm{cm}^{-3}\right)$. Being D (density), M (mass), V (volume).

Initial and final samples of each residue of the experiment were submitted to the Chemistry Laboratory (DS/FAEM / UFPel) for determination of organic carbon (C) - (wet combustion/Walkey Black at $0.01 \%$ ), total nitrogen $(\mathrm{N})$, total phosphorus $(\mathrm{P})$, total potassium $(\mathrm{K})$, Total calcium $(\mathrm{Ca})$, total magnesium $(\mathrm{Mg})$. The evaluations were carried out according to the methodology proposed by Tedesco et al. (1995).

\section{Results}

It was observed at the end of this study little variation, in all treatments, regarding the number of earthworms initially placed, as observed in Table 1 .

In relation to the macronutrient analyzes at the beginning and at the end of the experiment (Table 2), it was possible to observe for $\mathrm{P}, \mathrm{K}$ and $\mathrm{Mg}$ a larger amount in the treatments of animal origin when compared with those of vegetal origin. For N, treatments EO and BC were superior to the other treatments, in counterpart, in $\mathrm{EM}$ and $\mathrm{EB}$, the lowest values. For $\mathrm{Ca}, \mathrm{BC}$ treatment 
Table 1. Number of worms and cocoons and multiplication index obtained in treatments based on equine manure (EE), bovine manure (EB), sheep manure (EO), residue of coffee-drag (BC) and residue herb-checkmate (EM). Average of five replicates. UFPel, Pelotas / RS, 2016.

\begin{tabular}{|c|c|c|c|c|}
\hline \multirow{2}{*}{ Treatments } & \multicolumn{2}{|c|}{$\mathrm{N}^{0}$ earthworms } & \multirow{2}{*}{$\mathrm{N}^{0}$ cocoons } & \multirow{2}{*}{$\mathbf{I M}^{1}$} \\
\hline & Initial & Final & & \\
\hline EE & 150 & 151 & 16 & 1 \\
\hline EB & 150 & 151 & 34 & 1 \\
\hline EO & 150 & 236 & 323 & 1.57 \\
\hline BC & 150 & 148 & 16 & 0.99 \\
\hline EM & 150 & 164 & 123 & 1.09 \\
\hline
\end{tabular}

${ }^{1} \mathrm{IM}$ (Multiplication Index) $=($ Final population) / (Initial population).

Table 2. Chemical analysis of the macronutrients $\left(\mathrm{N}, \mathrm{P}, \mathrm{K}, \mathrm{Ca}\right.$ and $\mathrm{Mg}$ ), C, C/N ratio, $\mathrm{pH}$, humidity at $60-65{ }^{\circ} \mathrm{C}$ and volumetric density in the initial (i) and final (f) equine manure (EE), bovine manure (EB), sheep manure (EO), residue herb-checkmate (EM) and residue of coffee-drag (BC). UFPel, Pelotas/RS, 2016.

\begin{tabular}{|c|c|c|c|c|c|c|c|c|c|c|c|}
\hline \multirow{2}{*}{ Treatments } & \multirow{2}{*}{ Phase } & $\mathbf{N}$ & $\mathbf{P}$ & $\mathbf{K}$ & $\mathbf{C a}$ & Mg & C & \multirow{2}{*}{$\mathbf{C} / \mathbf{N}$} & \multirow{2}{*}{ pH } & \multirow{2}{*}{$\begin{array}{c}\text { Humidity } \\
(\%)\end{array}$} & \multirow{2}{*}{$\begin{array}{l}\text { Density } \\
\left(\mathrm{g} \mathrm{cm}^{-3}\right)\end{array}$} \\
\hline & & \multicolumn{6}{|c|}{$\mathrm{g} \mathrm{Kg}^{-1}$} & & & & \\
\hline \multirow[t]{2}{*}{$\mathbf{E E}$} & $\mathrm{i}$ & 19.43 & 7.50 & 13.96 & 4.40 & 3.77 & 260.75 & $13 / 1$ & 5.29 & 31.5 & 0.531 \\
\hline & $\mathrm{f}$ & 18.72 & 4.91 & 11.43 & 4.64 & 4.19 & 232.36 & $12 / 1$ & 4.95 & 26 & 0.506 \\
\hline \multirow[t]{2}{*}{ EB } & $\mathrm{i}$ & 16.07 & 9.06 & 17.19 & 6.57 & 7.9 & 228.21 & $14 / 1$ & 7.73 & 33.5 & 0.731 \\
\hline & $\mathrm{f}$ & 16.6 & 7.19 & 19.40 & 10.20 & 8.14 & 193.61 & $12 / 1$ & 6.51 & 34 & 0.628 \\
\hline \multirow[t]{2}{*}{ EO } & $\mathrm{i}$ & 24.55 & 9.95 & 20.68 & 12.51 & 7.6 & 352.62 & $14 / 1$ & 8.06 & 32.5 & 0.622 \\
\hline & $\mathrm{f}$ & 26.49 & 9.9 & 23.12 & 22.81 & 8.65 & 252.54 & $9 / 1$ & 6.37 & 29.5 & 0.582 \\
\hline \multirow[t]{2}{*}{ EM } & $\mathrm{i}$ & 14.48 & 0.59 & 2.95 & 8.63 & 2.86 & 419.61 & $29 / 1$ & 7.89 & 31 & 0.55 \\
\hline & $\mathrm{f}$ & 17.31 & 0.64 & 4.52 & 11.56 & 3.19 & 411.99 & $24 / 1$ & 7.88 & 24 & 0.48 \\
\hline \multirow[t]{2}{*}{ BC } & $\mathrm{i}$ & 22.79 & 1.28 & 5.91 & 2 & 1.63 & 559.78 & $24 / 1$ & 5.58 & 34 & 0.572 \\
\hline & $\mathrm{f}$ & 32.33 & 1.6 & 9.3 & 3.09 & 2.18 & 441.69 & $14 / 1$ & 6.31 & 27.5 & 0.544 \\
\hline
\end{tabular}

had the lowest value at the beginning of the experiment $\left(2 \mathrm{~g} \mathrm{Kg}^{-1}\right)$ and the highest at the end $\left(30.9 \mathrm{~g} \mathrm{Kg}^{-1}\right)$ when compared to the other treatments. The $\mathrm{C} / \mathrm{N}$ ratio was higher in residues of vegetal origin.

The initial $\mathrm{pH}$ in the EO, EM and EB treatments were high (above 7) and lower in treatments BC and EE (less than 6). At the end, only EM treatment remained high (7.88) and $\mathrm{EE}$ for the humidity at $60-65{ }^{\circ} \mathrm{C}$ initial values ranging from $31-34 \%$ (EM and $\mathrm{BC}$, respectively) and at the end a variation of $24-34 \%$ (EM and $\mathrm{EB}$, in this order) were found. The highest moisture variations during the experiment were observed in vegetal residues, $\mathrm{EM}(7.0 \%)$ and $\mathrm{BC}(6.5 \%)$ and the lowest variation in EB treatment $(0.5 \%)$.

The initial and final density in this study varied between the treatments, where the highest values were observed in $\mathrm{EB}, \mathrm{EO}, \mathrm{BC}$ and the lowest in EM and EE (Table 2).

\section{Discussion}

The species E. andrei and E. foetida have similar characteristics and behavior (Atiyeh et al., 2000), the results obtained in this work regarding the multiplication of the E. foetida species were compared with results presented in the literature for both species (Antoniolli et al., 2009).

In relation to the number of earthworms and cocoons found in this study, it is observed that the EO (Table 1) stood out from the other treatments, different from the results found by Huber and Morselli (2011), to vermicompost $\mathrm{EO}$ in wooden boxes in a protected environment in the FAEM/UFPel, this treatment being considered as the least expressive, this could have occurred due to the conditions of experimentation and the origin of the materials were different.

In the treatment with $\mathrm{EB}$, was observed a multiplication index of 1 , presenting a number of earthworms and cocoons inferior to those presented by Aquino et al. (1994), which obtained multiplication index 4.54, at 60 days after the inoculation of 5 matrices of $E$. foetida. In the same context, Pereira et al. (2005) found a multiplication index of 2.09 for earthworms inoculated in bovine manure (100\%) at the end of 62 days. However, it should be considered that this work was carried out in a period of the year that presents low temperatures, unfavorable to the development of earthworms and that was completed in 87 days, factors that may have influenced the final result of the experiment, since the suggested time for vermicomposting varies from 30-45 days (Morselli, 2009).

The highest $E$. foetida multiplication index observed in EO and EM treatments may be related to the chemical composition of these residues, especially with the high calcium content, as shown in Table 2. Similar results were observed by Steffen et al. (2010), that when evaluating the multiplication of earthworms of E. andrei species, found that the residues with the highest numbers of young individuals were the same ones that presented higher 
levels of calcium in the substrate. When evaluating the multiplication of worms of the species $E$. andrei, Castro et al. (2007) concluded that the addition of chicken eggshell in bovine manure favored the production of cocoons because it is a food rich in this nutrient.

The $\mathrm{BC}$ is not commonly used in natural in fertilization processes, since it presents the potential for organic compost only after being vermicompost (Cabral and Moris, 2010). Its acidity, when present in the greatest concentration, as reported by Silva et al. (1998), may have been a limiting factor to the growth and reproduction of earthworms in this study. In this context, Carlesso et al. (2011) emphasize that earthworms have a preference for low acidic organic matter and do not smell very strongly.

The low $\mathrm{C} / \mathrm{N}$ ratio observed in $\mathrm{EO}$ can be explained by the fact that the higher the number of individuals, the faster the compound stabilizes, the lower the $\mathrm{C} / \mathrm{N}$ ratio, the greater the cation exchange capacity and the greater the number of humic substances (Albanell et al., 1988).

The accelerated humification of vermicompost reflects a decrease in $\mathrm{C} / \mathrm{N}$ and an increase in mineral nutrients $(\mathrm{N}, \mathrm{P}$ and $\mathrm{K} \mathrm{e}$ ) and is related to the mineralization of $\mathrm{OM}$ by earthworms (Atiyeh et al., 2001). According to the analysis presented in Table 2, all treatments, except in EE, after the vermicomposting processes obtained a significant increase in $\mathrm{N}$ and $\mathrm{K}$ levels, when compared to the initial values. For P, only the vegetal residues (EM and BC) increased and differed from the initial values. The increase in $\mathrm{N}, \mathrm{P}$ and $\mathrm{K}$ levels in these vermicomposts may be associated with the ability of the earthworms, through their metabolism, to break down structures of organic compounds (Silva et al., 2002).

According to Garcia and Zidko (2006), the $\mathrm{pH}$ should be close to 7.0, although the worms tolerate environments with $\mathrm{pH}$ between 5.0 and 9.0. In this study, all treatments remained within this range, and corroborate with results found by Huber and Morselli (2011), who found a final $\mathrm{pH}$ of 7.7 (EM) and 6.3 (BC). This fact may have occurred because these materials came from the same places. The opposite was verified for residues EE (6.8) and EO (8.7), difference being also related to the different origins of the materials.

Elvira et al. (1998), concluded that the production of $\mathrm{CO}_{2}$ by microbial decomposition during vermicomposting reduces the $\mathrm{pH}$ of the substrate, as observed in all treatments, except for the BC that increased. Similarly, some studies (Ndegwa et al., 2000; Yadav and Garg, 2009) have pointed out that a change in $\mathrm{pH}$ may be related to the mineralization of $\mathrm{N}$ and $\mathrm{P}$ in nitrites and nitrates, orthophosphates and bioconversion of organic matter in species intermediates of organic acids. In the present study, the changes in the $\mathrm{pH}$ of the samples possibly related to the incorporation of organic acids, in the medium where the worms were inserted.

The final concentrations of $\mathrm{N}, \mathrm{P}, \mathrm{K}, \mathrm{Ca}$ and $\mathrm{Mg}$ were generally higher than the initial concentrations for all treatments, demonstrating maturation of vermicompost as well as nutritional potential, as suggested by Silva et al. (2011). The increase of $\mathrm{Ca}$ and $\mathrm{Mg}$ contents can be explained by the decrease in the volume of the substrate as a function of the capacity to accelerate the decomposition of organic matter (Aquino et al., 1992), results that collaborate with those found by Malafaia (2015).

\section{Conclusion}

- The sheep manure allows greater mating of Eisenia foetida, consequently more worms and cocoons;

- The $\mathrm{pH}$ of all substrates, with the exception of the equine vermicompost, are adjusted, at the end of vermicomposting, to a recommended value, and can, therefore, be applied as an organic fertilizer;

- The vermicomposts of vegetal origin have a higher $\mathrm{C} / \mathrm{N}$ ratio and lower values of the macronutrients $\mathrm{P}, \mathrm{K}$ and $\mathrm{Mg}$ when compared to vermicomposts of animal origin.

\section{Acknowledgements}

CAPES, Federal University of Pelotas and the Erva-mate Pantanal.

\section{References}

ALBANELl, E., PLAIXATS, J. and CABRERO, T., 1988. Chemical changes during vermicomposting (Eisenia foetida) of sheep manure mixed with cotton industrial wastes. Biology and Fertility of Soils, vol. 6, no. 3, pp. 266-269. http://dx.doi. org/10.1007/BF00260823.

ANTONIOLLI, Z.I., STEFFEN, G.P.K. and STEFFEN, R.B., 2009. Utilização de casca de arroz e esterco bovino como substrato para a multiplicação de Eisenia fetida Savigny (1826). Revista Ciência e Agrotecnologia, vol. 33, no. 3, pp. 824-830. http:// dx.doi.org/10.1590/S1413-70542009000300022.

AQUINO, A.M., ALMEIDA, D.L. and SILVA, V.F., 1992. Utilização de minhocas na estabilização de resíduos orgânicos: vermicompostagem. Rio de Janeiro: Centro Nacional de Pesquisa Biológica do Solo. 13 p. Comunicado Técnico, no. 8

AQUINO, A.M., ALMEIDA, D.L., FREIRE, L.R. and DEPOLLI, H., 1994. Reprodução de minhocas (Oligochaeta) em esterco bovino e bagaço de cana-de-açúcar. Pesquisa Agropecuária Brasileira, vol. 29, no. 2, pp. 161-168.

AQUINO, M.A. and NOGUEIRA, E.M., 2001. Fatores limitantes da vermicompostagem de esterco suíno e de aves e influência da densidade populacional das minhocas na sua reprodução. Seropédica: Embrapa Agrobiologia. 10 p.

ATIYEH, R.M., DOMÍNGUEZ, J., SUBLER, S. and EDWARDS, C.A., 2000. Changes in biochemical properties of cow manure during processing by earthworms (Eisenia andrei, Bouché) and the effects on seedling growth. Pedobiologia, vol. 44, no. 6, pp. 709-724. http://dx.doi.org/10.1078/S0031-4056(04)70084-0.

ATIYEH, R.M., EDWARDS, C.A., SUBLER, S. and METZGER, J.D., 2001. Pig manure vermicompost as a component of a horticultural bedding plant medium: effects on physicochemical proprieties and plant growth. Bioresource Technology, vol. 78, no. 1, pp. 11-20. http://dx.doi.org/10.1016/S0960-8524(00)00172-3. PMid:11265782

BASSACO, A.C., ANTONIOLLI, Z.I., JÚNIOR, B.S.B., ECKHARDT, D.P., MONTAGNER, D.F. and BASSACO, 
G.P., 2015. Caracterização química de resíduos de origem animal e comportamento de Eisenia andrei. Revista Ciência e Natura, vol. 37 , no. 1, pp. 45-51.

BAUMGARTEN, A., 2002. Methods of chemical and physical evaluation of substrates for plants. In: A.M.C. FURLANI, ed. Caracterização, manejo e qualidade de substratos para produção de plantas. Campinas: Instituto Agronômico. 122 p. Documentos IAC, no. 70.

BRASIL. Ministério da Agricultura, Pecuária e Abastecimento - MAPA, 2004. Instrução Normativa ${ }^{\circ} 14$, de 15 de dezembro de 2004. Aprova as Definições e Normas sobre as Especificações $e$ as Garantias, as Tolerâncias, o Registro, a Embalagem e a Rotulagem dos Substratos para Plantas, constantes do anexo desta instrução normativa. Diário Oficial da República Federativa do Brasil, Brasília, 15 dez. Seção 1, pp. 24.

BRASIL. Ministério da Agricultura, Pecuária e Abastecimento - MAPA, 2007. Instrução Normativa $n^{\circ} 17$, de 21 de maio de 2007. Aprova os Métodos Analíticos Oficiais para Análise de Substratos e Condicionadores de Solos, na forma do Anexo à presente Instrução Normativa. Diário Oficial da República Federativa do Brasil, Brasília, 24 maio.

CABRAL, M.S. and MORIS, V.A.S., 2010. Reaproveitamento da borra de café como medida de minimização da geração de resíduos. In: Anais do XXX Encontro Nacional de Engenharia de Produção, 2010, São Carlos. Rio de Janeiro: ABEPRO, pp. 1-9.

CARLESSO, W.M., RIBEIRO, R. and HOEHNE, L., 2011. Tratamento de resíduos a partir de compostagem e vermicompostagem. Revista Destaques Acadêmicos, vol. 3, no. 4, pp. 105-110.

CASTRO, A.R., COVA, L.J., GARCIA, D.E. and MEDINA, M.G., 2007. Efecto de La cáscara de huevo em laproducción de cápsulas de lalombriz roja (Eisenia andrei). Zootecnia Tropical , vol. 25, no. 2, pp. 135-142.

DORAN, J.W. and ZEISS, M.R., 2000. Soil health and sustainability: managing the biotic component of soil quality. Pretty. Applied Soil Ecology, vol. 15, no. 1, pp. 3-11. http://dx.doi.org/10.1016/ S0929-1393(00)00067-6.

ELVIRA, C., SAMPEDRO, L., BENITEZ, E. and NOGALES, R., 1998. Vermicomposting of sludges from paper Mill and dairy industries with Eisenia andrei: a pilot scale study. Bioresource Technology, vol. 63, no. 3, pp. 205-211. http://dx.doi.org/10.1016/ S0960-8524(97)00145-4.

FERMINO, M.H., 2014. Substratos: composição, caracterização e métodos de análise. Guaíba: Agrolivros. 112 p.

GARCIA, F.R.M. and ZIDKO, A., 2006. Criação de minhocas: as operárias do húmus. Porto Alegre: Ríegel. $112 \mathrm{p}$.

HUBER, A.C.K. and MORSELLI, T.B.G.A., 2011. Densidade populacional e número de casulos de Eisenia foetida em processo de vermicompostagem sob resíduos de origem vegetal e animal. Revista FZVA, vol. 18, no. 2, pp. 21-29.

LAVELLE, P. and SPAIN, A.V., 2001. Soil ecology. Dordrecht: Kluwer Academic Pub. 654 p. http://dx.doi.org/10.1007/97894-017-5279-4.

MALAFAIA, G., 2015. Aproveitamento de lodo de curtume e uso de água residuária de esgoto doméstico na cultura do milho (Zea mays L.). Goias: Universidade Federal de Goiás, 137 p. Tese de Doutorado em Agronomia.

MORSELLI, T.B.G.A., 2009. Resíduos orgânicos em sistemas agrícolas. Pelotas: Ed. Universitária. 228 p.

MOTA, F.S., SIGNORINI, E., ALVES, E.G.P. and AGENDES, M.O.O., 1993. Tendência temporal da temperatura no Rio Grande do Sul. Revista Brasileira de Agrometeorologia, vol. 1, pp. 101-103.
NADDAFI, K., ZAMANZADEH, M., AZIMI, A.A., OMRANI, G.A., MESDAGHINIA, A.R. and MOBEDI, E., 2004. Effect of temperature, dry solids and $\mathrm{C} / \mathrm{N}$ ratio on vermicomposting of wates activated sludge. Pakistan Journal of Biological Sciences, vol. 7, no. 7, pp. 1217-1220. http://dx.doi.org/10.3923/ pjbs.2004.1217.1220

NDEGWA, P.M., THOMPSON, S.A. and DAS, K.C., 2000. Effects of stocking density and feeding rate on vermicomposting of biosolids. Bioresource Technology, vol. 71, no. 1, pp. 5-12. http://dx.doi.org/10.1016/S0960-8524(99)00055-3.

PEREIRA, E.W.L., AZEVEDO, C.M.S.B., LIBERALINO FILHO, J., NUNES, G.H.S., TORQUATO, J.E. and SIMÕES, B.R., 2005. Produção de vermicomposto em diferentes proporções de esterco bovino e palha de carnaúba. Revista Caatinga, vol. 18, pp. 112-116.

RÖBER, R. and SCHALLER, K., 1985. Pflanzenernährung im Gartenbau. Stuttgart: Ulmer. 352 p.

SHARMA, S., PRADHAN, K., SATYA, S. and VASUDEVAN, P., 2005. Potentiality of earthworms for waste management and in other uses: a review. The Journal of American Science, vol. 1, pp. 4-16.

SILVA, C.D., COSTA, L.M., MATOS, A.T., CECON, P.R. and SILVA, D.D., 2002. Vermicompostagem de lodo de esgoto urbano e bagaço de cana-de-açúcar. Revista Brasileira de Engenharia Agrícola e Ambiental, vol. 6, no. 3, pp. 487-491. http://dx.doi. org/10.1590/S1415-43662002000300018.

SILVA, L.N. and AMARAL, A.A., 2013. Amostragem da mesofauna e macrofauna de solo com armadilha de queda. Revista Verde de Agroecologia e Desenvolvimento Sustentável, vol. 8, no. 5, pp. 108-115.

SILVA, M.A., NEBRA, S.A., MACHADO, M.J. and SANHEZ, C.G., 1998. The use of Biomassa Residues in the Brasilizian Soluble Coffee Industry. Biomass and Bioenergy, vol. 14, no. 5-6, pp. 457-467. http://dx.doi.org/10.1016/S0961-9534(97)10034-4.

SILVA, R.F., AQUINO, A.M., MERCANTE, F.M. and GUIMARÃES, M.F., 2006. Macrofauna invertebrada do solo sob diferentes sistemas de produção em latossolo da região do Cerrado. Pesquisa Agropecuária Brasileira, vol. 41, no. 4, pp. 697-704. http://dx.doi.org/10.1590/S0100-204X2006000400022.

SILVA, R.F., VASCONCELLOS, N.J.S., STEFFEN, G.P.K., DOTTO, R.B. and GRUTKA, L., 2011. Caracterizações microbiológicas e químicas em resíduos orgânicos submetidos à vermicompostagem. Revista Brasileira de Agrociências, vol. 17, pp. 108-115.

STEFFEN, G.P.K., ANTONIOLLI, Z.I., STEFFEN, R.B. and MACHADO, R.G., 2010. Casca de arroz e esterco bovino como substratos para a multiplicação de minhocas e produção de mudas de tomate e alface. Acta Zoológica Mexicana, no. 2, pp. 333-343.

TEDESCO, M.J., GIANELLO, C., BASSANI, C.A., BOHNEN, H. and VOLKWEISS, S.J., 1995. Análises de solo, plantas e outros materiais. Porto Alegre: Departamento de Solos, Faculdade de Agronomia, Universidade Federal do Rio Grande do Sul. 174 p.

WOLTERS, V., 2000. Invertebrate control of soil organic matter stability. Biology and Fertility of Soils, vol. 31, no. 1, pp. 1-19. http://dx.doi.org/10.1007/s003740050618.

YADAV, A. and GARG, V.K., 2009. Feasibility of nutrient recovery from industrial sludge by vermicomposting technology. Journal of Hazardous Materials, vol. 168, no. 1, pp. 262-268. http://dx.doi.org/10.1016/j.jhazmat.2009.02.035. PMid:19297091. 